DOI: http://dx.doi.org/10.4314/ljh.v25i1.8

\title{
A Minor Historical Rule of GRAVE Concern in the Volta-Comoe Languages
}

\author{
Lawrence Addai Boadi \\ Professor of Linguistics and Consultant at the Faculty of Language Education, University of \\ Education, Winneba, Ghana
}

\begin{abstract}
The Volta-Comoe languages ${ }^{1}$ belonging to Greenberg's (1963) Niger-Congo undergo a historical change in which underlying labial /b/ is reflexed as velar [g] and labio-palatal $[\mathrm{Ju}]$ in their Central members and as [b] in their Eastern and Western subgroups. We maintain that this process can be accounted for naturally by positing the feature Grave proposed by Jakobson, Fant and Halle (1956) in their early work on distinctive-feature phonology. This permits one to say that a non-back grave segment changed to a back one in specified linguistic contexts. Other processes which help explain the change are palatalisation, vowel-labialisation, consonant-labialisation and velar fronting.
\end{abstract}

Keywords: Volta-Comoe, grave, dialects, acute, palatalisation

Volta-Comoe has a minor linguistic rule which accounts for a sound change from morph-initial /b/ in its Eastern and Western members to /g/ in its Central (Akan group) members. The rule operates on a relatively small section of the lexicon of Volta-Comoe as can be seen from an examination of the entries in Christaller's Twi dictionary (1933) and also from the sample given on Table 1. Part of our interest in the data on the Table is to: (1) relate the apparently diverse phonetic forms $\left[\mathrm{b}^{\mathrm{w}}\right],\left[\mathrm{b}^{\mathrm{j}}\right],\left[\mathrm{g}^{\mathrm{w}}\right]$ and $[\mathrm{f} \mathrm{u}]$, which derived from the same underlying form; and (2) to account for their distribution in the various Volta-Comoe languages and their development from Early Volta-Comoe.

1 Following Stewart (1971), we use the term Volta-Comoe to refer to a sub-branch of Greenberg's Kwa languages of Niger-Congo in his classification of African languages (1963). For purposes of the discussion in this paper we divide Volta-Comoe into three genetically related languages as follows: (1) Eastern Volta-Comoe (EVC); (2) Western Volta-Comoe (WVC); and (3) Central Volta-Comoe (CVC). 
Table 1

Phonetic Reflexes of Early Volta-Comoe Grave Segments

\begin{tabular}{|c|c|c|c|c|c|}
\hline \multirow[t]{2}{*}{ Gloss } & \multicolumn{2}{|c|}{ E. Volta-Comoe } & \multirow{2}{*}{$\begin{array}{l}\begin{array}{l}\text { W. Volta- } \\
\text { Comoe }\end{array} \\
3 \\
\text { Nzema }\end{array}$} & \multicolumn{2}{|c|}{ Central Volta-Comoe } \\
\hline & $\begin{array}{l}1 \\
\text { Efutu }\end{array}$ & $\begin{array}{l}2 \\
\text { Larteh }\end{array}$ & & $\begin{array}{l}4 \\
\text { Akuapem, } \\
\text { Akwamu, } \\
\text { Fante }\end{array}$ & $\begin{array}{l}5 \\
\text { Akyem, } \\
\text { Asante } \\
\text { Kwawu, etc }\end{array}$ \\
\hline Sheep & & $b^{w} \mathrm{ui}$ & $b^{\mathrm{w}}$ uani & $\mathrm{g}^{\mathrm{w}} \mathrm{ay} / \mathrm{g}^{\mathrm{w}}$ an & Јчаn(I) \\
\hline Chair & $\mathrm{b}^{\mathrm{j}} \varepsilon$ & $b^{\mathrm{j}}$ ie & $\mathrm{b}^{\mathrm{j}} \mathrm{ia}$ & $\mathrm{g}^{\mathrm{w}}$ aII & лча \\
\hline $\begin{array}{l}\text { Urine / } \\
\text { Urinate }\end{array}$ & $b^{w}$ uru fo & $b^{\mathrm{w}} \mathrm{ur}^{\mathrm{w}} \mathrm{u}$ & $b^{\mathrm{j}}$ ie & $\mathrm{g}^{\mathrm{w}} \mathrm{a}(\mathrm{nsi})$ & J40n(nş) \\
\hline Bathe & $\mathrm{b}^{\mathrm{j}} \varepsilon \varepsilon$ & (ha) $b^{j}$ ie & $\mathrm{b}^{\mathrm{j}} \mathrm{ie}$ & $\mathrm{g}^{\mathrm{w}}$ ari, $\mathrm{g}^{\mathrm{w}}$ ar & કцаri \\
\hline Split & $\mathrm{b}^{\mathrm{j}} \mathrm{i \varepsilon}$ & $?$ & $\mathrm{~b}^{\mathrm{j}} \mathrm{ia}$ & $g^{w} a$ & лча \\
\hline Market & $\mathrm{b}^{\mathrm{j}} \varepsilon$ & $\mathrm{b}^{\mathrm{j}} \mathrm{i}$ & $\mathrm{b}^{\mathrm{j}} \mathrm{ia}$ & $g^{w} a$ & јча \\
\hline
\end{tabular}

The analysis will be restricted to initial phonetic $[\mathrm{b}]$ and $[\mathrm{g}]$ and their variants of $\mathrm{CV}$ structure.

\section{The Grave Segments /b/ and /g/}

The two morph-initial segments, /b/ and /g/, whose phonetic reflexes alternate in the major Volta-Comoe languages, are opposed in the phonetic features [Backness] and [Linguality]: the former is [-Back, -Lingual], and the latter [+Back, +Lingual]. If account is taken of the fact that both segments are 'peripheral' in the Jakobsonian sense, linguality can be predicted by a rule of redundancy. The two sounds may then be referred to as Grave, following Jakobson, Fant \& Halle (1956). Grave sounds 'have an ampler and less compartmented resonator than the corresponding [Acute] sounds (palatal and dental)' (Jakobson \& Halle, 1957, p. 235). They are further distinguished from the dental and palatal by a concentration of energy in the lower frequencies (Jakobson, 1957, p. 106).

In present-day Volta-Comoe languages, the two morph-initial segments [b] and [g] are reflexes of underlying $|\mathrm{b}|$. These occur, respectively, in Eastern-Western and Central Volta-Comoe and develop labialised and palatalised variants, $\left[\mathrm{b}^{\mathrm{w}} \mathrm{g}^{\mathrm{w}} \mathrm{b}^{\mathrm{j}} \mathrm{g}^{\mathrm{l}}\right]$ in 
specified phonetic contexts. In some of the Central dialects $\left[\mathrm{g}^{\mathrm{w}}\right]$ is further fronted and affricated, first to $\left[\mathrm{f}^{\mathrm{w}}\right]$, and then to $\left[\mathrm{f}^{\mathrm{T}}\right]$. These changes may be diagrammed as follows

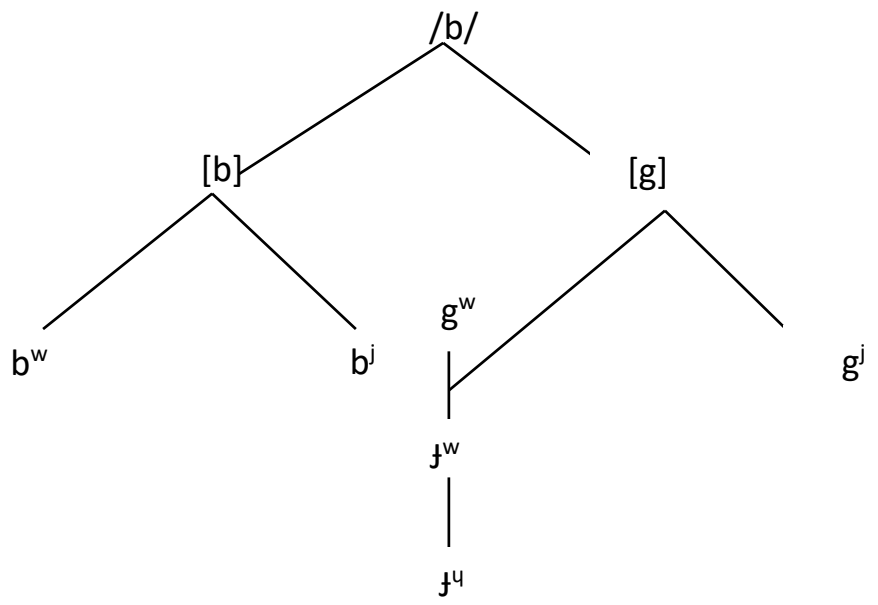

These changes will be discussed fully in the next sections.

\section{The Feature Grave}

The two segments, labial [b] and velar [g] were, in the 50s, classified by Jakobson and others (1952) in their feature theory as [+Grave] in contrast to the dentals, alveolars and palatals which were specified as [-Grave] or [+Acute]. The grouping of these sounds as Grave is based on acoustic and auditory properties which they share (Jakobson, Fant \& Halle 1956; Jakobson 1957). The classification is also backed by evidence from historical and morphophonemic changes found among the world's languages. For example, in both Hausa and Japanese there is a morphophonemic alternation between the grave sounds [h] and [f]. The two sounds alternate also in Effutu of Eastern Volta-Comoe.

As pointed out by Ladefoged (1971, p. 44), 'the acoustic (and hence auditory) similarities between corresponding sounds made in the labial and velar regions are often considerable.' This similarity 'led to the historical changes whereby $[\mathrm{x}]$ which occurred in Old English at the end of words such as rough and cough changed to [f].' Boadi (2009) discusses and illustrates the alternation of the grave sounds, [b, w, y] in Central and Western Volta-Comoe.

The basis for the introduction of the feature Grave into phonology has been questioned by Chomsky and Halle (1968). They argue that a feature approach to phonology should account for 'independently controllable aspects of the speech event' (Chomsky \& Halle, 1968, p. 298). Control in this context is interpreted to mean control 
by the speaker of the speech organs during the production of the speech event. It is argued that the postulation of the feature Grave is motivated by acoustic considerations; but speakers perceive sounds not directly in terms of speech waves (Stevens, 1972).

The attention of proponents of this view has been drawn to a requirement of morphophonemic alternation evidence of which is available in languages of the world, not only in their synchronic grammars but also in their processes of sound change. As stressed by Sommerstein (1977, p. 111), morphophonemic alterations 'are in large measure the debris of past phonological changes'. These changes are motivated in different ways, one of the significant of these being the perceptual. Two sounds that are not easy to distinguish auditorily may merge. Alternatively, such a process of merger may be blocked as a result of one of the two sounds acquiring a new feature, which makes the distinction easier to perceive. The distinction perceived at this stage is at the acoustic level and not auditorily based (Sommerstein, 1997). It is in consideration of such factors that a number of features, including grave and sonorant, whose status is questionable judged from the purely auditory point of view becomes relevant as soon as the requirement of morphophonemics is taken into account.

The choice of features for a theory of phonology, while guarding against indiscipline and arbitrariness, should at the same time be comprehensive enough to account for data in all natural languages. It should also satisfy criteria based on synchronic and diachronic knowledge at all levels of linguistic study, including the morphophonemic, articulatory and acoustic levels.

There should even be room 'for seeking insight into universal speech and hearing mechanisms' (Fant, 2006, p. 175; Ladefoged, 2007, p. 190). It should not be forgotten that some of the early work on features by Jakobson benefited from insight into studies of aphasia and child language learning.

\section{Analysis of the Data}

The phonetic data on the Table show that the Eastern and Western Volta-Comoe languages (EVC and WVC) have morph-initial voiced palatalised and labialised labial plosives, $\left[\mathrm{b}^{\mathrm{j}}\right]$ and $\left[\mathrm{b}^{\mathrm{w}}\right]$, while some of the Central dialects have the labialised velar plosive, $\left[\mathrm{g}^{\mathrm{w}}\right]$. Labialised $\left[\mathrm{g}^{\mathrm{w}}\right]$ in the Central dialects has in certain cases fronted to palatal, resulting in $\left[\mathrm{f}^{\mathrm{w}}\right]$ (or $[\mathrm{f} \mathrm{y}]$ ). The $[\mathrm{b}] /[\mathrm{g}]$ change involves a shift from one major point of articulation of a grave sound to another, accompanied by the secondary articulations of palatalisation and labialisation. These two minor processes occur extensively in all present-day VoltaComoe languages (Aidoo, 2010; Boadi, 2009; Dolphyne, 2006; Eminah, 2010). Below we give brief formal accounts of each of these secondary articulations. 


\section{Palatalisation}

In general, Volta-Comoe consonants are palatalised when followed by a highfront vowel (Boadi, 1986, 2010). More formally, the generalisation may be expressed as Rule 1 below:

\section{Rule 1: Palatalisation:}

$$
\mathrm{C} \rightarrow[+\mathrm{Pal}] \text { in } /-\left(\begin{array}{c}
+ \text { Syll } \\
- \text { Cons } \\
- \text { Back } \\
+\mathrm{High}
\end{array}\right)
$$

Examples of the application of the rule of palatalisation can be seen in Columns 1-3 of the Table and below

\begin{tabular}{|c|c|c|c|c|c|}
\hline i) & /bie/ & $\rightarrow$ & {$\left[\mathrm{b}^{\mathrm{j}} \mathrm{ie}\right]$} & chair & (Larteh) \\
\hline ii) & /bie/ & & [b $\left.\mathrm{b}^{\mathrm{j}} \mathrm{ie}\right]$ & bathe & (Larteh) \\
\hline iii) & /bia/ & & [b $\left.\mathrm{b}^{\mathrm{j}} \mathrm{ia}\right]$ & chair & (Nzema) \\
\hline iv) & /bse/ & & {$\left[\mathrm{b}^{\mathrm{j}} \varepsilon \varepsilon\right]$} & chair & (Effutu) \\
\hline
\end{tabular}

\section{Labialisation}

Volta-Comoe vowels and consonants are lip-rounded in the appropriate phonetic context. These processes are referred to as consonant labialisation and vowel labialisation, respectively. By the rule of consonant labialisation, Volta-Comoe consonants become rounded if followed by a rounded (or back) vowel (see Table 1). This is expressed formally in Rule 2.

\section{Rule 2: Consonant Labialisation}

$$
\mathrm{C} \rightarrow[+ \text { Round }] \text { in } / \longrightarrow\left(\begin{array}{c}
+ \text { Syll } \\
- \text { Cons } \\
+ \text { Round }
\end{array}\right)
$$


The following examples are taken from Table 1.
2. i) /buru fa/
$\left[b^{\mathrm{w}} \mathrm{ur}^{\mathrm{w}} u \mathrm{f}^{\mathrm{w}} \mathrm{v}\right]$
urinate
(EVC: Effutu)
ii) /bui/
$\left[b^{\mathrm{w}} \mathrm{ui}\right]$
sheep
(EVC: Larteh)
iii) /guanI/
$\rightarrow\left[\mathrm{g}^{\mathrm{w}}\right.$ uanI $]$
sheep
(CVC: Akyem, Akuapem, Fante)

In a number of cases, front (unrounded) vowels become rounded or backed if preceded or followed by a labial consonant. This rule, though not much commented on in the literature of these languages, accounts for a number of changes in the synchronic grammars.

For example:

3.
i) Fante [betumi] $\rightarrow \quad$ [botumi] $\rightarrow \quad\left(\mathrm{b}^{\mathrm{w}}\right.$ otumi) will be able to
ii) Twi [afia] $\rightarrow \quad$ [afua] $\rightarrow \quad\left[æ \mathrm{f}^{\mathrm{w}} \mathrm{ua}\right]$ Afua (personal name)
iii) Twi $[\mathrm{fam}] \quad \rightarrow \quad[\mathrm{fæm}] \rightarrow\left[\mathrm{f}^{\mathrm{w}} \mathrm{\textrm {rm }}\right] \quad$ on the ground
iv) Fante $[\mathrm{fam}] \quad \rightarrow \quad[\mathrm{fem}] \longrightarrow\left[\mathrm{f}^{\mathrm{w}} \mathrm{om}\right] \quad$ on the ground
v) Twi [ajuvamansa] $\rightarrow$ [ajuvo mansa] Adwoa Mansah (personal name)
vi) Fante $\left[\mathrm{k}^{\mathrm{w} \text { ајчо }]} \rightarrow \quad\left[\mathrm{k}^{\mathrm{w}}\right.\right.$ ајчо $] \rightarrow \quad\left[\mathrm{k}^{\mathrm{w}}\right.$ ојчо $]$ Kojo (personal name)
vii) Fante $\left[\mathrm{k}^{\mathrm{w}}\right.$ abina $] \rightarrow \quad\left[\mathrm{k}^{\mathrm{w}}\right.$ obina $] \quad$ Kwabena (personal name)

This rule is crucial in accounting for some of the changes which occurred in the development of the lexical items on the Table.

This generalisation is expressed as Rule 3 below. 


\section{Rule 3: $\quad$ Vowel Labialisation}

$$
[+ \text { Syll }] \rightarrow[+ \text { Round }] / \longrightarrow\left(\begin{array}{l}
+ \text { Cons } \\
- \text { Syll } \\
+ \text { Round }
\end{array}\right)
$$

\begin{tabular}{|c|c|c|c|c|}
\hline $\begin{array}{l}\text { i) } / \text { biru/ } \rightarrow \\
\text { ii) } / \text { brani } / \rightarrow \\
\text { iii) } / \text { biri fo/ } \rightarrow\end{array}$ & $\begin{array}{l}\text { [buru] } \\
\text { [buanI] } \\
\text { [buru fo] }\end{array}$ & $\begin{array}{l}\rightarrow \\
\rightarrow\end{array}$ & $\begin{array}{l}{\left[b^{\mathrm{w}} u \mathrm{ru}\right]} \\
{\left[\mathrm{b}^{\mathrm{w}} \mathrm{uani}^{\mathrm{w}}\right]} \\
{\left[\mathrm{b}^{\mathrm{w}} \mathrm{rr}^{\mathrm{w}} u \mathrm{f}^{\mathrm{w}} \mathrm{r}\right]}\end{array}$ & $\begin{array}{l}\text { urine } \quad(E V C) \\
\text { sheep } \quad(E V C) \\
\text { urinate }(\text { Effutu }(E V C)\end{array}$ \\
\hline
\end{tabular}

\section{Positing an Underlying Morph-initial Grave Segment for Volta-Comoe}

Before stating the Gravity Shift Rule, there is at least one question to be resolved, and that has to do with the underlying form of the two grave segments under discussion. In making this decision, one should be guided by the fact that from independent comparative evidence, Western Volta-Comoe languages (Nzema, Ahanta, Aowin, Sehwi and Anyi-Baoule) have more in common with Central Volta Comoe (Akyem, Asante, Akuapem and Fante) than they do with Eastern Volta-Comoe (Effutu and Larteh) in terms of the number of shared cognates and phonological rules required to link underlying and surface phonetic forms. The relationship may be represented diagrammatically as follows:

\section{Early Proto-Volta-Comoe}

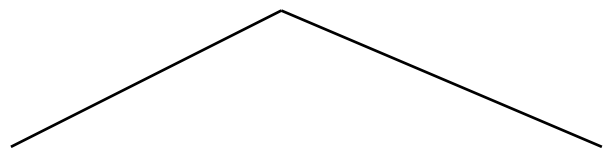

Eastern Volta-Comoe

(i) Western Volta-Comoe and

(ii) Central Volta-Comoe

Since both Eastern VC and Western VC have morph-initial [b] in the synchronic phonology of the lexemes under consideration we can assume that Early Volta-Comoe also had [b] morph-initially before it split into Eastern and the rest.

Eastern and Western retained [b] while Central changed [b] to [g]. Central dialects like Akuapem and Fante retained [g]. Dialects like Akyem, Akuapem, Asante, Dankyira and Kwawu, on the other hand, changed velar [g] (grave) to palatal [f] (acute). 
These changes were accompanied in most cases by processes of secondary articulation. In addition to the rules of palatalisation and labialisation which apply in all the VoltaComoe languages, we need a rule which accounts for the change of front grave [b] to back grave [g]. We refer to this rule as Gravity Shift.

\section{Rule 4 Gravity Shift Rule}

$[+$ Grave $] \longrightarrow[+$ Back $]$ (Central Volta-Comoe)

This rule is to be interpreted to mean: [b] in morph-initial position changed to back grave [g] in Central Volta-Comoe. For example

5)
i) [bianI]
[guani]
sheep
(Fante, Akuapem)
ii) $[$ bia] $\rightarrow \ldots \ldots$. [gua]
market; split, chair
(Fante, Akuapem)
iii) $[$ bia fo] $\rightarrow \ldots \ldots$. [gua (nsi)]
(urinate)
(Fante, Akuapem)

The dots indicate that a number of rules are to apply prior to the change to [g]. Below we illustrate the order of application of the rules discussed so far.

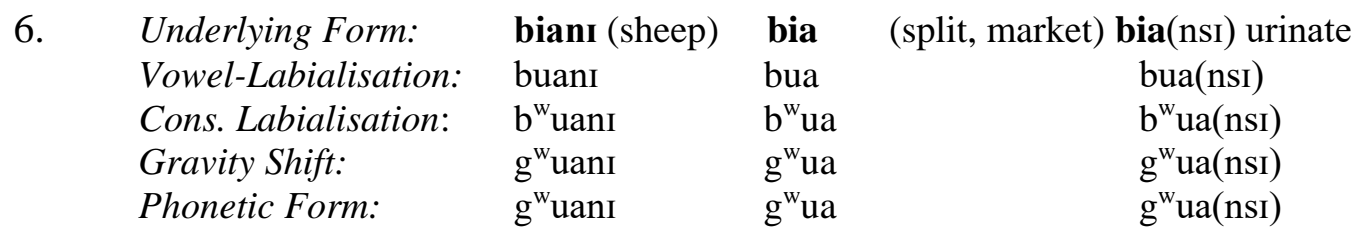

\section{Desyllabification}

There is a rule in the synchronic grammar of Akan Central Volta-Comoe by which a high-vowel is elided in the environment of the low vowel/a/. This rule is referred to by Schachter and Fromkin (1968) as U-Deletion and I-Deletion. The explanation seems to me to be that, in the environment of the most sonorous vowel /a/, a high vowel loses its syllabicity and becomes a (consonantal) glide. This is a more satisfactory explanation from a phonetic point of view. For this reason, we refer to the process as High-vowel Desyllabification (Boadi, 2010). The rule may be stated as below. 
Rule 5: High-Vowel Desyllabification

-Cons $\left(\begin{array}{c}+ \text { Syll } \\ + \text { High }\end{array}\right) \longrightarrow\left(\begin{array}{c}\text {-Syll } \\ \text { in C } / \longrightarrow\end{array}\left(\begin{array}{c}+ \text { Syll } \\ + \text { Low }\end{array}\right)\right.$

As a result of the application of this rule the final phonetic forms in the derivations of (6) become (7):

$\begin{array}{llll}\text { 7. } & \text { i) } & {\left[\mathrm{g}^{\mathrm{w}} \mathrm{wanI}\right]} & \text { sheep } \\ & \text { ii) } & {\left[\mathrm{g}^{\mathrm{w}} \mathrm{wa}\right]} & \text { market, split } \\ & \text { iii) } & {\left[\mathrm{g}^{\mathrm{w}} \mathrm{wa}(\mathrm{nsI})\right]} & \text { urinate }\end{array}$

In (7) above, it is important to distinguish between the superscript [ $\left.{ }^{\mathrm{w}}\right]$, which symbolises secondary articulation of lip-rounding, and the symbol [w], which represents the non-syllabic back glide. The difference between the two representations is theoretical: labialistion of the initial consonant is predictable from the presence of the following back glide.

\section{From Grave to Acute}

In dialects, such as Akyem, Asante, Dankyira and Kwawu of Central VoltaComoe, velar [g] which resulted from the application of the Gravity Shift rule was fronted to the palatal point of articulation possibly after being palatalised. The process may be summarised as follows:
i)
$\mathrm{g}^{\mathrm{w}}$
$\mathrm{g}^{\mathrm{jw}}$
by Palatalisation
ii)

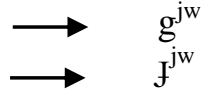
by Velar Fronting (Palatality)

One has to assume that palatalisation is conditioned by the presence of a front vowel in underlying structure. By a series of phonological rules already discussed, the phonetic forms in Akyem, Asante and Kwawu are derived. Below is one example of derivation. 


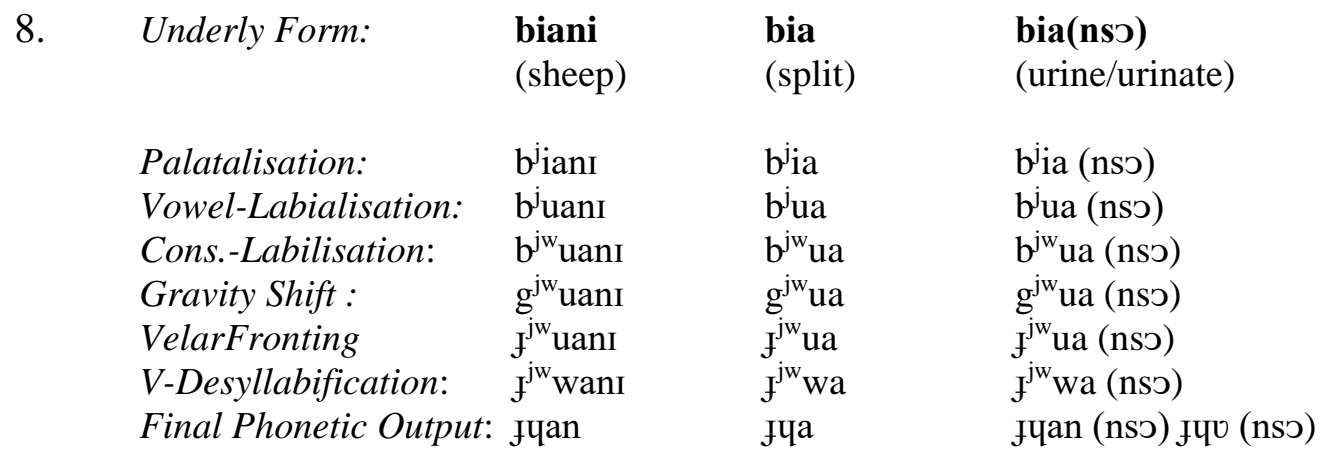

The rule of Velar-Fronting (our Grave to Acute) is widespread among languages. It is found in Russian, Ancient and Modern Greek and several others (Chomsky and Halle 1968; King 1969; Newton 1972; Sommerstein 1973). In Akan, it accounts for the changes below. In all cases, a palatal plosive changes to an affricate.

Eg.

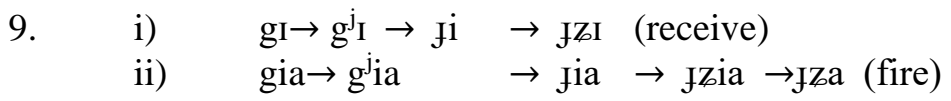

It is not intended to group lexical items for fire and receive in Example (9) with those on Table 1. Their underlying forms are different. The relevant point is that Velar Fronting is as much a major phonological process in at least some of the Volta-Comoe languages as they are in languages, such as Czech, Russian and Greek.

We now return to the data on Table 1 . To explain the change in morph-initial position in the Akyem, Asante and Kwawu forms of Akan in Column 5, we say the original Grave sound [g] shifted to Non-Grave [f]. More, formally, this may be expressed as Rule 6.

Rule 6: Grave-to-Acute Rule

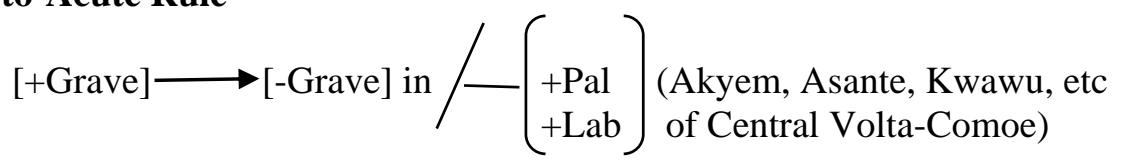

By this rule, $\left[\mathrm{g}^{\mathrm{w}}\right],\left[\mathrm{g}^{\mathrm{j}}\right]$ change to palatal sounds. The changes from Grave to Acute are natural processes. 


\section{Conclusion}

In this paper, we have sought to show the relevance of the feature Grave to an explanation of one historical process in Volta-Comoe. We have not attempted to compare the Jakobson-Halle-Fant feature-system with any other. However, we think the feature Grave explains the historical change from /b/ to [g] in Volta-Comoe as simply as any other set of features (eg. The Chomsky-Halle System). This is not to claim that the feature Grave should replace Chomsky's alternative features. We take the view that there is a pool of features from which languages select to account for phonological processes, and the feature Grave is one of these. 


\section{References}

Aidoo, R. A. (2010). The morphophonemics of the Effutu verb and noun (Unpublished MPhil dissertation), University of Education, Winneba, Ghana.

Boadi, L. A. (1988). Palatalisation in Akan. Journal of West African Languages 18, 3-16.

Boadi, L. A. (2009). A comparative phonological study of verbal affixes in seven Volta-Comoe languages. Accra, Ghana: Black Mask.

Chomsky, N. \& Halle, M. (1968). The sound pattern of English. New York, NY: Harper and Row.

Christaller, J. G. (1933). A dictionary of the Asante and Fante languages called Tshi (Chwee, Twi). Basel, Switzerland: Evangelical Missionary Society.

Dolphyne, F. A. (2006). The Akan (Twi-Fante) language. Its sound system and tonal structure. Accra: Woeli Publishing Services. (Original work published 1988)

Eminah, M. (2010). The morphophonemics of the Nzema verb and noun. (Unpublished MPhil dissertation), University of Education, Winneba, Ghana.

Fant, G. (2006). Speech acoustics and phonetics: Selected writings. Dordrecht, Netherlands: Kluwer.

Greenberg, J. H. (1963). The languages of Africa. The Hague, Netherlands: Mouton.

Jakobson, R., Fant, C. G. M., \& Halle, M. (1956). Preliminary to speech analysis. Cambridge, MA: MIT Press.

Jakobson, R. (1957). Mufaxxama-The emphatic phonemes in Arabic: Synchronic and diachronic aspects. In E. Pulgram (Ed.), Studies Presented to Joshua Whatmough (pp. 105-115). The Hague, Netherlands: Mouton.

King, R. D. (1969). Historical linguistics and generative grammar. Englewood Cliffs, NJ: Prentice Hall.

Ladefoged, P. (1971). Preliminaries to linguistic phonetics. Chicago, IL: University of Chicago Press.

Ladefoged, P. (2007). Review of Fant: Speech acoustics and phonetics. Language, 83, 183-191.

Newton, B. (1972). The generative interpretation of dialect: A study of Modern Greek phonology. Cambridge, UK: Cambridge University Press.

Pulgram, E. (Ed.), (1957). Studies presented to Joshua Whatmough. The Hague, Netherlands: Mouton.

Schachter, P., \& Fromkin, V. (1968). A phonology of Akan: Akuapem, Asante and Fante. UCLA working papers in phonetics, 9. California: UCLA.

Sommerstein, A. H. (1973). The sound pattern of ancient Greek. Oxford, UK: Blackwell.

Sommerstein, A. H. (1977). Modern phonology. London, UK: Edward Arnold.

Stevens, K. N. (1972). Segments, features and analysis by synthesis. In J. F. Kavanagh

\& I. C. Mattingly (Eds.), Language by ear and by eye (pp. 47-52). Cambridge, MA: MIT Press.

Stewart, J. M. (1971). Niger-Congo Kwa. Current Trends in Linguistics, 7, 119-212. 